\title{
Premedication modifies the quality of sedation with propofol during regional anesthesia

\author{
$\mathrm{M}$ asashi $\mathrm{N}$ akagawa $\mathrm{M} \mathrm{D}$,* \\ Tadanori M ammoto MD,* \\ Toshiko Sakai MD,* \\ Yoshihiko Kishi MD,* \\ Takashi Mashimo M D†
}

Purpose: To determine the effects of diazepam or clonidine on the quality of sedation with propofol during regional anesthesia.

M ethods: In a prospective randomised, controlled, double-blinded study, 60 patients undergoing elective gynecological surgery were studied. They were given premedication with 0.15 -mg clonidine ( $G$ roup $-C L, n=20$ ), 5 mg diazepam (Group-DZ, $n=20$ ), or placebo (Group-P, $n=20$ ) po. After spinal anesthesia was established, sedation was provided with propofol and controlled using a five-point sedation score at 3, "eyes closed but rousable to command", and 4, "eyes closed but rousable to mild physical stimulation". During sedation, blinded anesthesiologist recorded occurrence of complications. At two hours after end of sedation, patients were asked if they had intraoperative dream and memory.

Results: The loading dose, steady-state infusion rate, and overall mean infusion rate in Group-CL were 0.80 $\mathrm{mg} \cdot \mathrm{kg}^{-1}, 2.35 \mathrm{mg} \cdot \mathrm{kg}^{-1} \cdot \mathrm{hr}^{-1}$ and $2.89 \mathrm{mg} \cdot \mathrm{kg}^{1} \cdot \mathrm{hr}^{-1}$, compared with $0.97 \mathrm{mg} \cdot \mathrm{kg}^{1}, 3.13 \mathrm{mg} \cdot \mathrm{kg}^{-1} \mathrm{hr}^{-1}$ and 3.59 $\mathrm{mg} \cdot \mathrm{kg}^{-1} \cdot \mathrm{hr}^{-1}$ in Group-DZ, and $1.38 \mathrm{mg} \cdot \mathrm{kg}^{-1}, 4.10 \mathrm{mg} \cdot \mathrm{kg}^{-1} \cdot \mathrm{hr}^{-1}$ and $4.36 \mathrm{mg} \cdot \mathrm{kg}^{-1} \cdot \mathrm{hr}^{-1}$ in Group-P, respectively. Indices of both G roup-CL $(P<0.001)$ and Group-DZ $(P<0.05)$ were smaller than those of Group-P. Moreover, clonidine reduced the incidence of uncontrolled movement $(P<0.01)$, while diazepam reduced the incidence of intraoperative memory and increased the incidence of dream $(P<0.05)$. Premedication did not affect the incidence of other complications.

Conclusion: Both premedicants reduced propofol requirements and exerted beneficial effects on the incidence of some complications during sedation with propofol as an adjunct to regional anesthesia.

O bjectif : Déterminer les effets du diazépam ou de la clonidine sur la qualité de la sédation avec du propofol pendant l'anesthésie régionale.

M éthode : L'étude prospective, randomisée, contrôlée et à double insu a été menée auprès de 60 patientes qui devaient subir une intervention gynécologique planifiée. Une prémédication avec $0,15 \mathrm{mg}$ de clonidine (Groupe $C L, n=20$ ), $5 \mathrm{mg}$ de diazépam ( $G$ roupe $D Z, n=20$ ), ou un placebo (Groupe $P, n=20$ ) po a d'abord été administrée. Puis, une rachianesthésie a été réalisée et une sédation fournie avec du propofol et contrôlée en utilisant un score de sédation en cinq points où le point 3 dit "yeux fermés mais se réveille sur commande" et le point 4, "yeux fermés, mais se réveille avec une stimulation physique légère". Pendant la sédation, un anesthésiologiste impartial a enregistré l'occurrence de complications. Deux heures après la fin de la sédation, on a demandé aux patientes si elles ont eu des rêves ou se souviennent d'événements peropératoires.

Résultats : La dose de charge, la vitesse de perfusion à l'état d'équilibre et la vitesse de perfusion globale moyenne ont été, dans le Groupe $C L$ de $0,80 \mathrm{mg} \cdot \mathrm{kg}^{-1}$, de $2,35 \mathrm{mg} \cdot \mathrm{kg}^{-1} \cdot \mathrm{h}^{-1}$ et de $2,89 \mathrm{mg} \cdot \mathrm{kg}^{-1} \cdot \mathrm{h}^{-1}$, comparées à $0,97 \mathrm{mg} \cdot \mathrm{kg}^{-1}, 3,13 \mathrm{mg} \cdot \mathrm{kg}^{-1} \cdot \mathrm{h}^{-1}$ et $3,59 \mathrm{mg} \cdot \mathrm{kg}^{-1} \cdot \mathrm{h}^{-1}$ dans le Groupe $\mathrm{DZ}$, et à $1,38 \mathrm{mg} \cdot \mathrm{kg}^{-1}, 4,10 \mathrm{mg} \cdot \mathrm{kg}^{-1} \cdot \mathrm{h}^{-1}$ et $4,36 \mathrm{mg} \cdot \mathrm{kg}^{-1} \cdot \mathrm{h}^{-1}$ dans le Groupe $P$, respectivement. Les indices des Groupes $C L(P<0,001)$ et $D Z(P<0,05)$ ont été plus bas que celui du Groupe $P$. De plus, la clonidine a réduit l'incidence de mouvements incontrôlés ( $P$ $<0,01$ ), tandis que le diazépam a réduit l'incidence de mémoire pero pérato ire et a augmenté l'incidence de rêve $(P<0,05)$. La prémédication n'a pas eu d'effet sur l'incidence d'autres complications.

Conclusion : Les deux prémédications ont réduit les besoins de propofol et produit des effets bénéfiques sur l'incidence de certaines complications pendant la sédation avec du propofol comme adjuvant à l'anesthésie régionale.

From the D epartments of Anesthesiology,* O saka M edical Center for Cancer and Cardiovascular D iseases,* and O saka U niversity Graduate School of M edicine, $†$ O saka, Japan.

A ddress correspondence to: D r. M asashi N akagawa, D epartment of Anesthesiology, $\mathrm{O}$ saka $\mathrm{M}$ edical $\mathrm{C}$ enter for $\mathrm{C}$ ancer and $\mathrm{C}$ ardiovascular

D iseases, 1-3-3 N akamichi, O saka City, 537-8511, Japan. Phone: 81-6-6972-1181; Fax: 81-6-6981-4060; E-mail: m.h.naka@4.dion.ne.jp A ccepted for publication $\mathrm{N}$ ovember 9, 2000. 


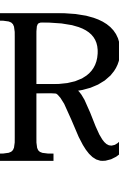

EGIONAL anesthesia with supplemental sedation is often performed for patient comfort during lower abdominal surgery. Propofol infusion is useful for providing sedation during regional anesthesia. ${ }^{1,2} \mathrm{H}$ owever, the sedatives may also cause uncontrolled movement, ${ }^{3}$ and dose-dependent cardiovascular and respiratory depression. These may be important clinical considerations for its use as an adjunct to spinal anesthesia.

Clonidine has some ideal properties for premedication, such as producing sedation, attenuating autonomic nervous system responses and reducing anesthetic requirements. ${ }^{4-6}$ Thus, preanesthetic clonidine may modify the clinical course of propofol sedation. Diazepam is also often prescribed for premedication due to its anxiolytic, sedative, and amnesic effects. M oreover, benzodiazepines and propofol act synergistically. ${ }^{3,7,8}$ It is possible that preanesthetic diazepam reduces the propofol requirements and decreases the complications. Both drugs are useful for premedication, however, there are few reports to investigate the differences between them when used as premedicants for sedation with propofol. The aim of this study is to compare the effects of the two premedicants on quality of sedation with propofol.

M ethods

The Hospital Ethics Committee approved this randomised, placebo-controlled study and informed consent was obtained from 60 patients undergoing elective gynecological laparotomy under spinal anesthesia. Criteria for entry into the study were: ASA physical status I or II, age 25-65 yr, and no recent psychotropic medication. The patients received oral premedication with $0.15-\mathrm{mg}$ clonidine (Group-CL, $\mathrm{n}=20$ ), $5-\mathrm{mg}$ diazepam (Group-DZ, $n=20$ ), or placebo (Group-P, $\mathrm{n}=20$ ) in a double-blind, randomised fashion $120 \mathrm{~min}$ before arrival at the operating room.

In the operating room an iv line was inserted and all patients were monitored with ECG, non-invasive automatic blood pressure and pulse oximetry. After baseline measurements, an epidural catheter was placed through the $\mathrm{L}_{2-3}$ interspace for postoperative pain relief and epidural placement was ascertained by injection $2 \mathrm{ml}$ lidocaine $1 \%$ with epinephrine (1:100000). Then, according to patient height, spinal anesthesia was instituted with an intrathecal injection of 2.5 or $3 \mathrm{ml}$ tetracaine $0.4 \%$ and glucose $10 \%$ via a 25-gauge needle through the $\mathrm{L}_{3-4}$ and analgesia was obtained to at least the $\mathrm{T}_{4}$ level.

After placement of a small sampling tube in the nasal vestibule to monitor respiratory rate and expired carbon dioxide partial pressure, sedation was started.
TABLE I Sedation scores ${ }^{1}$

\begin{tabular}{ll}
\hline Score & D egrœ of sedation \\
\hline 1 & Fully awake and orientated \\
2 & D rowsy \\
3 & Eyes closed but rousable to command \\
4 & Eyes closed but rousable to mild physical stimulation \\
& (earlobe tug) \\
5 & Eyes closed but unrousable to mild physical stimulation \\
\hline
\end{tabular}

Propofol was given at a rate of $6 \mathrm{mg} \cdot \mathrm{kg}^{-1} \cdot \mathrm{hr}^{-1}$ until verbal command diminished or disappeared. Then, the infusion rate was reduced to $3 \mathrm{mg} \cdot \mathrm{kg}^{-1} \mathrm{hr}^{-1}$ and adjusted to maintain a sedation score between 3 and 4 on a 5-point scale ${ }^{1}$ ( $T$ able I) by a blinded anesthesiologist. Infusion of propofol was stopped at the end of the operation. The loading dose (LD dose), steady state infusion rate (SS rate), and overall infusion rate (OA rate) of propofol were recorded to compare the requirements among the groups. The LD dose was the dose administered until response to verbal command diminished or disappeared, SS rate was the infusion rate when steady state sedation level was obtained, and $\mathrm{OA}$ rate was the value divided total dose of propofol during sedation by duration of sedation.

Ephedrine, $4 \mathrm{mg}$, was injected when blood pressure decreased $<80 \%$ of baseline level, $0.25 \mathrm{mg}$ atropine was administered when heart rate decreased to $<45$ beat $\min ^{-1}$. Supplemental oxygen, $31 \cdot \mathrm{min}^{-1}$, was given when $\mathrm{SpO}_{2}$ decreased to $<95 \%$. A pnea was defined as the absence of expired $\mathrm{CO}_{2}$ and respiratory movement for $>15 \mathrm{sec}$.

The overall sedation score and complications such as apnea, uncontrolled movement, frequency of ephedrine or atropine injection, and supplemental oxygen requirements were also recorded. Uncontrolled movement is purposeless movement of arms or trunk, which might disturb the operative procedure.

T wo hours after the end of sedation, patients were asked if they had dreamed or remembered intraoperative questions that we asked about nausea and pain during sedation.

Continuous data were summarised using mean \pm SD and analysed using one-way AN OVA. Alternations in heart rate or blood pressure were analysed using the repeated-measure MANOVA. Discrete data was reported as numbers and analysed using a chi-square test. A value of $P<0.05$ was considered statistically significant. 
Results

All groups were similar with respect to age, height, weight, overall sedation score, and duration of the surgical and anesthetic procedures (Table II). Clonidine reduced LD dose, SS rate, and OA rate to $58.0 \%$, $57.3 \%$ and $66.3 \%$ compared with those in Group-P, respectively $(P<0.001)$. Diazepam also decreased LD dose, SS rate, and OA rate to $70.3 \%, 76.3 \%$ and $82.3 \%$ compared with those in Group- $P$, respectively ( $P$ $<0.05$ ) (T able II).

Preanesthetic clonidine reduced the incidence of uncontrolled movement $(P<0.01)$; preanesthetic diazepam decreased the incidence of intraoperative memory and increased the incidence of intraoperative dreams ( $P<0.05)$. N o patients complained about their dreams. Both premedicants had no effects on other intrao perative complications (Table III).

Systolic blood pressure at start of sedation was higher in Group- $P$ than in other groups $(P<0.01)$, differences among groups disappeared at 30 min after the start. D iastolic blood pressure at the start of sedation was lower in Group-CL than in Group-P ( $P<$ $0.05)$, differences among groups also disappeared at 30 min after the start. H eart rate in Group-CL was lower than in Group-P during infusion of propofol ( $P$ $<0.001$ ). In spite of these hemodynamic differences, the frequency of atropine and ephedrine administration was similar (data not shown).

Changes of the $\mathrm{SpO}_{2}, \mathrm{P}_{\mathrm{ET}} \mathrm{C} \mathrm{O}_{2}$ value and respiratory rate were comparable in the three groups during sedation (Table IV). Although transient desaturation during induction was commonly observed in all groups, it was easy to treat with supplemental oxygen.

\section{Discussion}

In this study, both clonidine and diazepam reduced the propofol requirement for induction and maintenance of sedation. M oreover, clonidine decreased the incidence of uncontrolled movement, while diazepam decreased the incidence of intraoperative memory.

Recently, we reported that preanesthetic clonidine relieved anxiety and reduced the requirement of propofol for general anesthesia. ${ }^{6}$ These beneficial effects of clonidine are produced by activation of $\alpha 2$ adrenoceptor in the central nervous system. ${ }^{9}$ The propofol sparing effect of clonidine described in this paper is also probably related to this central nervous system attenuating effect of clonidine.

Spontaneous excitatory movement has been observed during induction and recovery from propofol anesthesia, ${ }^{10,11}$ and also during sedation using propofol. ${ }^{1} \mathrm{H}$ owever, this excitatory movement seems to be different from uncontrolled movement.
TABLE II Demographic data for patients

\begin{tabular}{llll}
\hline & Group-P & Group-CL & Group-DZ \\
\hline Age $(\mathrm{yr})$ & $45.3 \pm 10.4$ & $44.0 \pm 9.4$ & $47.7 \pm 10.3$ \\
Weight $(\mathrm{kg})$ & $56.1 \pm 7.5$ & $51.2 \pm 5.9$ & $54.5 \pm 6.1$ \\
H eight $(\mathrm{cm})$ & $154.6 \pm 5.1$ & $155.2 \pm 5.7$ & $154.8 \pm 5.7$ \\
Duration of anesthesia (min) & $108.5 \pm 26.4$ & $99.8 \pm 21.0$ & $103.2 \pm 21.0$ \\
Duration of surgery (min) & $72.2 \pm 24.8$ & $62.9 \pm 20.8$ & $65.7 \pm 18.7$ \\
O verall sedation score (3/ 4) & $17 / 3$ & $19 / 1$ & $18 / 2$ \\
Propofol requirements & & & \\
$\quad$ LD dose $\left(\mathrm{mg}^{\prime} \mathrm{kg}^{-1}\right)$ & $1.38 \pm 0.61$ & $0.80 \pm 0.29 * 0.97 \pm 0.32 \dagger$ \\
$\quad$ SS rate $\left(\mathrm{mg} \cdot \mathrm{kg}^{-1} \cdot \mathrm{hr}^{-1}\right)$ & $4.10 \pm 1.23$ & $2.35 \pm 0.71 * 3.13 \pm 1.06 \dagger$ \\
$\quad$ OA rate $\left(\mathrm{mg}^{\prime} \mathrm{kg}^{-1} \cdot \mathrm{hr}^{-1}\right)$ & $4.36 \pm 1.06$ & $2.89 \pm 0.80 * 3.59 \pm 0.88 \dagger$ \\
\hline
\end{tabular}

*P $\varangle .001$ lower than control group

$\dagger P \varangle 0.05$ lower than control group

TABLE III Incidence of intraoperative complications

\begin{tabular}{llll}
\hline & $\begin{array}{l}\text { Group-P } \\
(n=20)\end{array}$ & $\begin{array}{l}\text { Group-CL } \\
(n=20)\end{array}$ & $\begin{array}{l}\text { Group-DZ } \\
(n=20)\end{array}$ \\
\hline Uncontrolled movement & 7 & $0^{*}$ & 3 \\
Intraoperative memory & 8 & 4 & $1^{*}$ \\
Intraoperative dream & 2 & 1 & $9 \dagger$ \\
Application of oxygen & 17 & 17 & 18 \\
Apnea & 6 & 5 & 6 \\
Vomiting & 2 & 1 & 1 \\
Airway obstruction & 3 & 3 & 3 \\
Vascular pain & 16 & 15 & 12 \\
\hline
\end{tabular}

$* P<0.01$ lower than control group

$\dagger P<0.05$ higher than control group

TAB LE IV The respiratory parameters during sedation

\begin{tabular}{lccc}
\hline & Group-P & Group-CL & Group-DZ \\
\hline $\mathrm{SpO}_{2}(\%)$ & & & \\
$\quad$ Baseline & $97.9 \pm 1.2$ & $97.6 \pm 1.0$ & $98.1 \pm 1.2$ \\
$\quad$ D uring induction & $92.9 \pm 2.7$ & $94.0 \pm 2.1$ & $93.8 \pm 1.4$ \\
$\quad$ D uring sedation & $99.3 \pm 0.8$ & $99.3 \pm 0.8$ & $99.1 \pm 0.8$ \\
$\quad$ After the end of sedation & $97.6 \pm 1.3$ & $97.6 \pm 0.9$ & $97.4 \pm 1.5$ \\
Respiratory rate (times/ min) & & & \\
$\quad$ Baseline & $16.6 \pm 3.1$ & $16.7 \pm 3.0$ & $17.0 \pm 4.1$ \\
$\quad$ D uring sedation & $20.3 \pm 4.9$ & $19.1 \pm 3.1$ & $19.7 \pm 3.2$ \\
$\quad$ After the end of sedation & $17.7 \pm 3.8$ & $18.4 \pm 3.6$ & $18.4 \pm 4.8$ \\
$\mathrm{P}_{\mathrm{ET}} \mathrm{C} \mathrm{O}_{2}$ (mmH g) & & & \\
Baseline & $37.2 \pm 4.0$ & $38.4 \pm 6.0$ & $37.6 \pm 2.5$ \\
$\quad$ During sedation & $41.3 \pm 3.7$ & $39.4 \pm 6.9$ & $40.1 \pm 5.9$ \\
After the end of sedation & $38.6 \pm 2.6$ & $37.5 \pm 6.5$ & $35.9 \pm 5.6$ \\
\hline
\end{tabular}

All values are means \pm SD

Communication with the patient is possible when the latter occur, but is impossible with the former. If uncontrolled movement occurs during sedation, it may interfere with surgery. Benzodiazepine had no effect ${ }^{3}$ but clonidine inhibited it. This effect of clonidine is an advantage for sedation with propofol. 
The sympatholytic property of clonidine ${ }^{4}$ might induce serious bradycardia and hypotension when clonidine is used as premedication for sedation with propofol as an adjunct to spinal anesthesia. In our study, clonidine reduced heart rate compared with other groups but the incidence of bradycardia requiring treatment was similar in other groups. It is also reported that $0.15-0.2 \mathrm{mg}$ clonidine is appropriate for premedication and high dose clonidine increases cardiovascular adverse effects. ${ }^{12,13} \mathrm{It}$ is suggested that $0.15 \mathrm{mg}$ preanesthetic clonidine could be used safely for sedation with propofol as an adjunct to spinal anesthesia.

Both benzodiazepines and propofol activate $\mathrm{GABA}_{\mathrm{A}}$-coupled chloride channels, and produce anesthesia. ${ }^{14-17}$ Therefore, benzodiazepine reduces propofol requirements probably due to its synergistic action on $\mathrm{GABA}_{A}$ - receptor. ${ }^{3,7,8}$

Although we maintained the same sedation level in all groups, fewer patients in Group-DZ recalled intraoperative events than in other groups. Benzodiazepines, including diazepam, produce anterograde amnesia, and this may contribute to this reduction of the memories of intraoperative events. As intraoperative memories may cause patient's discomfort, diazepam may be a useful preanesthetic medication for spinal anesthesia with sedation.

In conclusion, preanesthetic clonidine or diazepam reduced propofol requirements for sedation. In addition, clonidine decreased the incidence of uncontrolled movement, while diazepam decreased intraoperative memory. Both premedicants are useful premedicants when sedation with propofol is planned for regional anesthesia.

\section{References}

1 Mackenzie N, Grant IS. Propofol for intravenous sedation. Anaesthesia 1987; 42: 3-6.

2 Wilson E, David A, Mackenzie N, Grant IS. Sedation during spinal anaesthesia: comparison of propofol and midazolam. Br J Anaesth 1990; 64: 48-52.

$3 \mathrm{~N}$ akagawa $\mathrm{M}, \mathrm{M}$ ammoto $\mathrm{T}, \mathrm{H}$ azama $\mathrm{A}$, et al. $M$ idazolam premedication reduces propofol requirements for sedation during regional anesthesia. Can J Anesth 2000; 47: 47-9.

4 Ghignone M, Calvillo O, Quintin L. Anesthesia and hypertension: the effect of clonidine on perioperative hemodynamics and isoflurane requirements. Anesthesiology 1987; 67: 3-10.

5 Ghignone M, N oeC, C alvillo O, Quintin L. Anesthesia for ophthalmic surgery in the elderly: the effects of clonidine on intraocular pressure, perioperative hemodynamics, and anesthetic requirement. Anesthesiology 1988; 68: 707-16.
6 I mai $Y$, Mammoto T, M urakami $K$, et al. The effects of preanesthetic oral clonidine on total requirement of propofol for general anesthesia. J Clin Anesth 1998; 10: 660-5.

7 McClune S, M CK ay AC, Wright PM C, Patterson CC, ClarkeR SJ . Synergistic interaction between midazolam and propofol. Br J Anaesth 1992; 69: 240-5.

8 Tzabar Y, Brydon C, Gillies GWA . Induction of anaesthesia with midazolam and a target-controlled propofol infusion. Anaesthesia 1996; 51: 536-8.

9 Maze M, Tranquilli W. Alpha-2 adrenoreceptor agonists: defining the role in clinical anesthesia. Anesthesiology 1991; 74: 581-605.

10 Borgeat A, D essibourg C, Popovic V, M eier D, Blanchard $M$, Schwander $D$. Propofol and spontaneous movements: an EEG study. Anesthesiology 1991; 74: 24-7.

11 Borgeat A, Wilder-Smith OH G, D espland PA, R avussin $P$. Spontaneous excitatory movements during recovery from propofol anaesthesia in an infant: EEG evaluation. Br J Anaesth 1993; 70: 459-61.

12 Carabine U A, Wright PMC, M oore J. Preanaesthetic medication with clonidine: a dose-response study. $\mathrm{Br}$ J Anaesth 1991; 67: 79-83.

13 Ota K, N amiki A, I wasaki H, Takahashi I. D ose-related prolongation of tetracaine spinal anesthesia by oral clonidine in humans. Anesth Analg 1994; 79: 1121-5.

14 Concas A, Santoro G, M ascia M P, Serra M, Sanna E, Biggio G. The general anesthetic propofol enhances the function of -aminobutyric acid-coupled chloride channel in the rat cerebral cortex. J N eurochem 1990; 55: 2135-8.

15 Goodchild CS. GABA receptors and benzodiazepines. Br J Anaesth 1993; 71: 127-33.

$16 \mathrm{H}$ ara $\mathrm{M}, \mathrm{K}$ ai $\mathrm{Y}, \mathrm{I}$ kemoto $\mathrm{Y}$. Enhancement by propofol of the -aminobutyric acid $A$ response in dissociated hippocampal pyramydal neurons of the rat. Anesthesiology 1994; 81: 988-94.

17 Davies PA, H anna MC, H alesTG, K irknessEF. Intensitivity to anaesthetic agents conferred by a class of $G A B A_{A}$ receptor subunit. $N$ ature $1997 ; 385$ : 820-23. 